Olena Stasyuk

\title{
CONSERVATION OF MEMORIAL MONUMENTS AT HISTORICAL CEMETERIES - CHALLENGES AND PERSPECTIVES
}

\author{
Doctoral student in the Department of Architecture and Cjnservation \\ Lviv Polytechnic National University, Lviv \\ olena.stasyuk@gmail.com \\ orcid: 0000-0002-2986-6321
}

Received: 10.04.2019/Revised: 23.06.2019/Accepted: 20.07.2019

C Stasyuk O., 2019

\begin{abstract}
The article analyzes the main restoration problems facing the restorer when working with memorial monuments at the historical cemetery. The method of solving these problems is offered on the example of diploma works of students of the specialty "Stone art works conservation" of the Architecture and Conservation Department of "Lviv Polytechnic". NU.
\end{abstract}

Key words: conservation, memorial monuments, natural stone, historical cemetery.

\section{Formulation of the problem}

Historical cemeteries are an integral part of the cultural landscape of each city or town, evidence of the ideology and spiritual life of their time. In many settlements of Ukraine cemeteries have been preserved, which we now call historical, and which today are potential memorials and are of interest to researchers and admirers of history, architecture, and art. Three Ukrainian cemeteries have the status of reserves: The State Historical and Memorial Lukyaniv Reserve in Kiev, the State Historical and Cultural Museum "Lychakivskyi Cemetery" in Lviv and the Cultural Reserve on the Green Street in Chernivtsi. This status should protect them from destruction and give the possibility of conducting research work. Thus, cemeteries in large cities already are the museums or can become them. The cemeteries of small settlements - towns, villages, are smaller, but, as a rule, they are examples, actually the collections of folk memorial sculpture.

Regardless of the size and status of the cemetery, there is no object in Ukraine in an absolutely perfect condition. Each cemetery requires uninterrupted care and ordering. Unfortunately, there are many historical cemeteries that are in an exceptionally neglected and poore condition. Such cemeteries require the ordering and conservation as a whole object, as well as the restoration of individual samples of the memorial monuments.

Still, the main material on the cemetery is a stone, although metal, wood and other materials also exist, but the stone clearly dominates. So, we work with stone. Below we are talking about restoration problems and methods of work with memorial monuments at the historical cemeteries on the example of diploma works of the students of the Architecture and Restoration Department of Lviv Polytechnic NU. 


\section{Analysis of recent research and publications}

The author relies on state regulatory documents of Ukraine. In particular, if necessary to perform the additions the composition of the restoration mass is in accordance with the State Building Regulations in the section "Restoration, conservation and repair works on cultural heritage monuments" - an official document approved by the order of the State Building Committee of Ukraine (SBC B.3.2-1-2004.).

One of the most comprehensive and most powerful works relating to the restoration of stone monuments was published in 2011 in Torun at the University of M. Copernicus (Domasłowski, 2011). The book is written by a team of authors and edited by Professor W. Domasłowski. The book is based on the great practical experience and a modern research base and is a true vocabulary for every young restorer. The book contains tips for dealing with biopsy, salt, patina, and the like.

In Lviv Polytechnic National University the catalogs of diploma work of students of the specialty " stone art works cconservation "are published (Bevz, M., Stasyuk, O., 2016), (Bevz, M., Stasyuk, O., 2017) These publications provide a brief description of each work and present work photos before and after conservation, and the most interesting fragments of the restoration documentation and work process. The photographs can clearly trace the volume of these works and their philosophy.

\section{The purpose of the article}

The purpose is to show the main problems that happen during the conservation of the memorial monuments on the historical cemeteries on the specific examples, to highlight the methods and techniques used to eliminate these problems and to offer options for preventive action to maximize the preservation of restored memorials.

\section{Presentation of the main material}

Speaking of the memorial monuments conservation at the historical cemetery come out that the history has developed in such a way that many of these cemeteries were partially or completely ruined and destroyed. The memorial monuments of such cemeteries often becomes part of museum collections, lapidary, sometimes private collections, and so on. Such facilities usually require restoration. So in 2016 a section of the cross with a crucifixion from the tombstone was transferred to the Department of Architecture and Conservation by the Museum of Sacral Art named after Anton Petrushevich, Lviv diocese of the UGCC for restoration works. A memorial was found at the cemetery in the village Nemyriv Yavoriv district, Lviv region. This work was performed and defended in the same year by the student Hanchevska Olena. Material and technique of execution indicated that the cross belongs to the Brusno masonry school. (Lew, S., 1967, c 193). The monument was created at the last 19-th - early 20-th century. Material - limestone, technique of execution - carving in a stone. The crucifix was broken down below the knees of Jesus. Stars are placed around the head of the Cross (solar signs); It is assumed that this cross was with two settlers that are lost. When entering the conservation, the condition of the object was unsatisfactory (Fig. 1). The lower part of the cross with the legs of Jesus is lost, and both arms from the elbow to the wrists are lost, and the upper part of the cross is opaque. The object was in a contaminated state with a layer of dust, dirt and cement mortar and biodeterioration. During the restoration, the cross was cleaned of dirt, cement mortar, patina, biodeterioration, and salinity of the monument was eliminated. The addition of the lost part of the cross was made of artificial stone. The reinforcement was use. Lost pieces were modeled and supplemented in artificial stone. The invoice has been executed, and the monument has been strengthened (Fig. 2). The monument is kept in the museum of Sacral Art named after Anton Petrushevich.

The nravestone monument in the form of a cross decorated with the Crucifix was particularly widespread in the cemeteries near Lviv in XIX - early XX- th century. (Kuzenko, P., 2008, c. 69-73). 
This is a time of a special rise in the stone processing industry. Stone memorial monuments in the form of cross with a crucifix is artistically enriched, developed and complicated and becomes a significant element of folk art (Mozdir, M., 2009).

The Museum of Sacred Art possesses a large collection of stone sacral monuments, and in 2016 and 2017 it transfers to the Architecture and Restoration Department a number of monuments that originate from the village of Nemirov, Yavoriv district. It is a white stone cross with a crucifix with the lost lower part of the cross and the face of Jesus. When entering the conservation, the cross was in a contaminated state with a layer of dust, earth, limestone, patina and a large number of different kinds of biodeterioration. The restoration of this object was performed by student Yankiv Nastya. In the process of restoration, the cross with a crucifix was cleane of surface contaminants, patinas and biodeterioration. Supplemented lower part of the cross that was lost. Created texture like a natural stone. The stone is strengthened. One more tombstone monument in the form of crucifix with the forthcoming was restored by student Makaruk Marina in 2017. When entering the conservation, the cross was in a satisfactory condition. the main parts of the monument are preserved. There was an insignificant loss on the drapery of the tissue coming. The monument is covered with dust and dirt, biodeterioration. and patina. The monument was thoroughly cleared from the dirt, patina and biodeteriorations, an addition was made.

The next gravestone monument in the form of a cross with the coming, which entered the conservation in 2018, was damaged already much more seriously (Fig. 3). At the time of receipt for conservation the cross was break into two parts, there was no left arm, the body of Jesus, the drapery, the wreath on the head of Jesus, the heads of the coming were damaged. The monument was covered with dust and dirt, mosses. The monument was thoroughly cleared of pollution and mosses. All parts were glued and armed. The losses have been supplemented the left arm of the cross, the end of the right arm, the body of Jesus, the heads of the coming (Fig. 4).

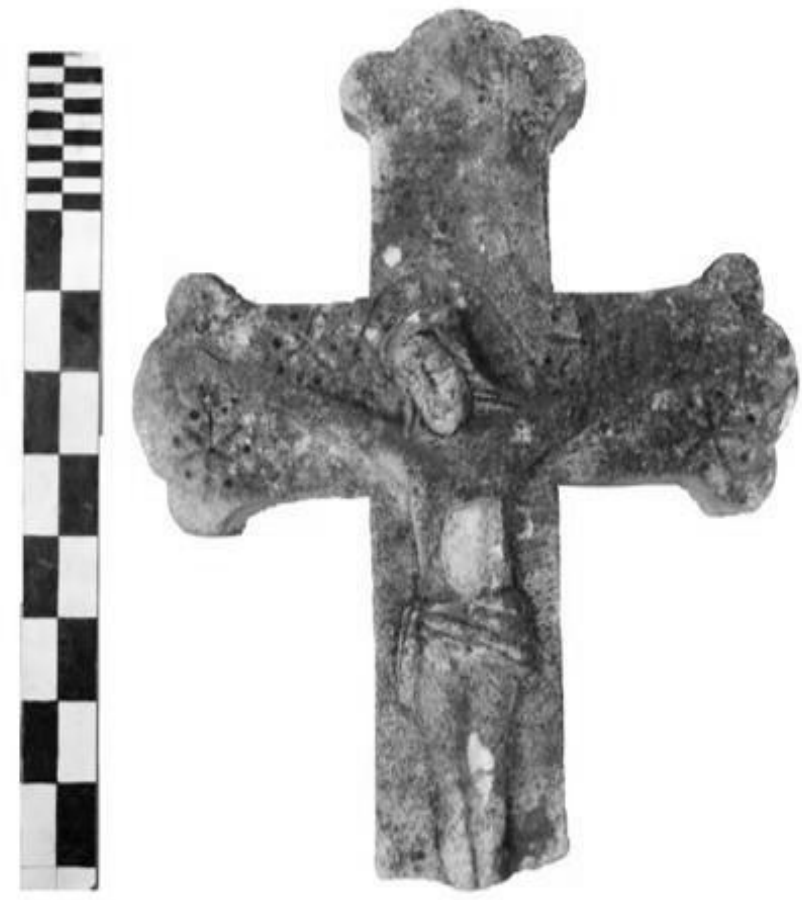

Fig. 1. Object at the time of receipt for conservation

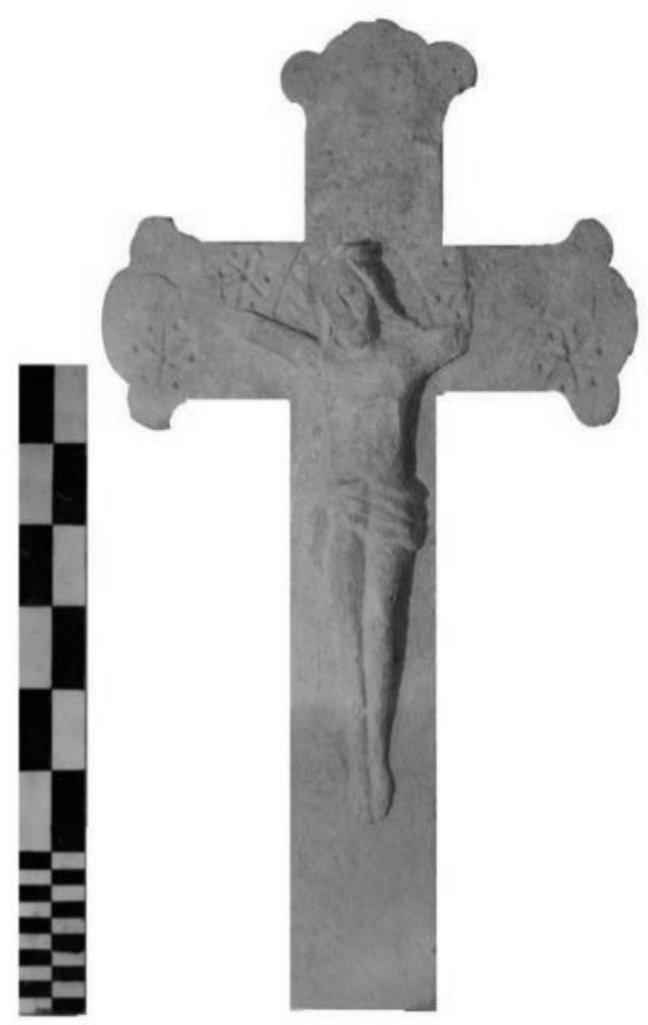

Fig. 2. Object after performing of conservation work 




Fig. 3. Object at the time of receipt for conservation

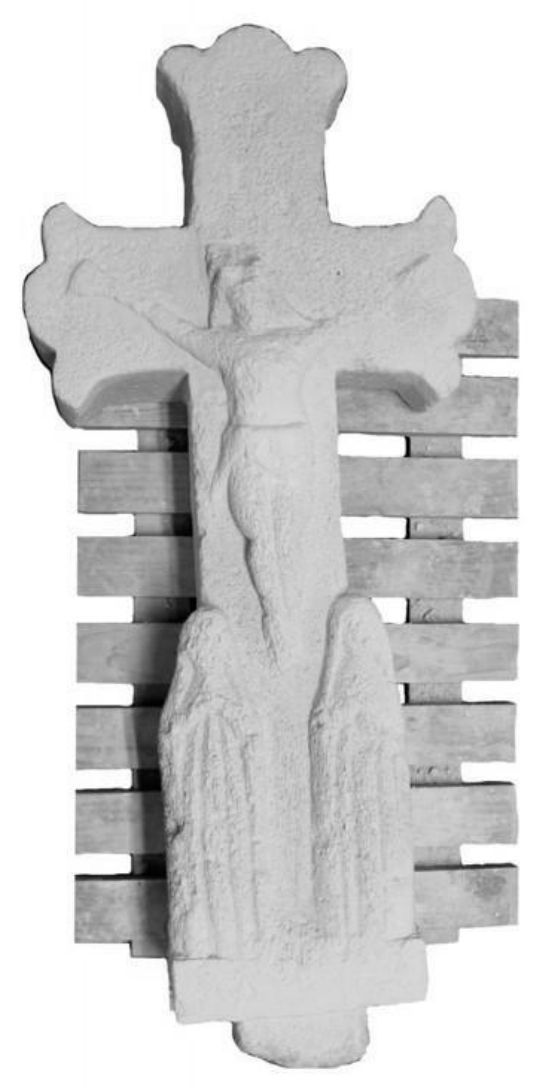

Fig. 4. Object after performing of conservation work.

Most seriously damaged monument in the form of a cross with the Crucifixion and coming receipt for conservation in 2017. The cross comes from the non-existent Ukrainian village of Sukha Volya, which is currently located in the Podkarpackie Voivodship of the Republic of Poland. At the time of receipt for conservation, the condition of the object was critical. Crucifixion was broken into nine separate parts (Fig. 5). The crucifix itself was broken into two part, the right figure from the cross was broken into two, the left - for three parts. Two more parts were repulsed from the corners of the cross, from the upper and lower. Probably the stone cross broke down when falling. For a long time, the monument was underground so the time of receipt for the conservation it was very dirty. Pores contain a large number of different types of biodeteriorations. The conservation was carried out by student Vlasyuk Julia. According to the technique of execution and the origin of the monument was attributed to the Brusno stonemasonry school. During the conservation, the cross was cleared of surface contaminants and biodeteriorations that were found in limestone pores. After complete cleaning, connection and gluing of parts of the stone cross, as well as addition of lost elements were carried out. The object was strengthened and colore unification was carried out (Fig. 6).

In addition to crosses with crucifixes and forthcoming as memorial monuments in our historical cemeteries, there are also so-called "figures". This is a different size of round sculptures, most often the Virgin Mary with or without child, Jesus Christ, or some of the Saints. Such a sculpture is a vivid example of folk art. So in 2016 the Museum of Sacred Art transferred for the conservation a white stone sculpture of the Virgin Mary with the Child. The Virgin and the Child are depicted in the crowns. The Virgin is depicted with the child, Jesus Christ sitting on Her hand and pressed his cheek to her cheeks. During the work it was found out that the sculpture comes from p. Chemeryntsi village, Peremyshlyany district, Lviv region. Old pictures were found on which the sculpture is already lying on the ground. That 
is, the sculpture itself collapsed, or was scattered to the ground. Mechanical damage and loss is obviously the result of a fall.

At the time the monument was received for the conservation it was in poor condition - The figure was covered with dust and biodeteriorations, there were insignificant layers of cement mortar on the lower part of the figure. The sculpture was completely covered with several layers of oil paints. Several fingers on the arms and legs were lost (Fig. 7). During the conservation work the sculpture was completely cleared of paint. The biodeteriorations and cement layers were eliminated. Recover lost parts. Stone was strengthened. A colored unification was carried out (Fig. 8).

Within the framework of diploma master's works the theme of conservation of the memorial monuments of the historical cemetery was considered more widely than restoration of a separate tombstone monument. In 2016, the area of distribution of the Brusno masonry school monuments was investigated by the student Gritsiv Olga. And a map of the distribution of these monuments on both sides of the modern Ukrainian-Polish border has been completed (Fig. 9). The methodology of inventory was analyzed, and the algorithm of research and restoration of the memorial legacy of the Brusno masonry school is drawn up. The information about the cemetery in the village Smolin of Yavoriv district was worked out, its partial inventory and conservation of one tombstone was carried out. The peculiarity of this work is that the restoration itself was carried out directly at the cemetery. The object of restoration was covered with dirt, dust, marsh and very clearly visible mosses. The monument, selected for restoration, stood firmly on the ground, did not flutter, did not fall and did not have any mechanical damage. Was thoroughly cleansed and strengthened. And it stayed in it's proper place.

A similar work in 2015 was conducted at the New Jewish Cemetery in Brody town by students Yulia Kostetska and Zenik Shulba. In 1835 - the Austrian authorities allocated for Jewish community in the Brody the land under a new cemetery. The cemetery was also marked on cadastres and military maps. He was given the name "New Jewish Cemetery". A detailed and complete inventory of a whole cemetery was conducted. The character and peculiarities of the memorial carving, as well as polychrome and color symbolism of the matsevs were investigated. Regarding polychromy: so it was possible to investigate it. It is clear that, initially, all mattsevs on the cemetery were colored. However, today polychromy is preserved on matsev, only in those places that were least exposed to adverse natural factors, as it were in the lower part, or part which was hidden by other mattsevs or were in the soil. That is, today we can reconstruct the color of the mattsevs. In the main graves at the cemetery belong to the 19 th century and the most recent ones to the 30s of the 20th century. Two mattsev were found made in the barco style. By artistic analysis one can assume that they belong to the late 18th century. The latest graves are dated 1939. As for the inventory then really huge work was carried out (Fig. 10). I want to submit calculations. At the cemetery in Brody, the largest matsevs are more than three meters high, and the smallest are only $30 \mathrm{~cm}$ high. The cemetery contains approximately 8120 matsevs, but only 5477 whole matsevs have been preserved, lying and destroyed matsevs in the amount of 539 pieces, of which the undamaged lying is 356; lying split into two parts is 40; lying split into many parts is 37 ; lying matsevs broken near the base is 83; The split fragments of matsevs are 13, and the stone bases in the amount of 2118 and yet an unknown number of tombstones was lost. For today, the cemetery is not functioning, but we can say that it is preserved. Some of the tombstones fell, but this is obviously a natural process. There are no traces of intentional target destruction or vandalism. In addition to the research work, each student conservated to two mattsevs. At the time of receipt for conservation, the selected mattsev were in an unsatisfactory condition. The monuments were contaminated with earth, patina, mosses, lichens, the stone was partially crushed. Significant mechanical damage and loss were present. Mattsevs were cleaned, dissolved, eliminated biological contamination, made gluing and addition of lost parts, the insertion of cracks and fugging stitches, color unification and strengthening. was conducted. All problems that caused the destruction of the stone were removed. Authenticity of the object is preserved. 
In 2018, a study of a cemetery on Chernecha mountain in the village of Univ, near the town of Peremyshlyany was conducted by the student Taras Hrin. In Univ, the architectural complex of one of the largest Christian shrines of Galicia - Assumption Univ Lavra has preserved. There is no exact information about the date of the monastery's foundation, but in the documents of the beginning of the 14th century, Univ is mentioned as one of the spiritual centers of Galicia. It was in the second half of the 13th century in the northwest of Chernecha Hill a new Univ male monastery rise up. After the ruin and tragedy Chernecha Mountain almost two centuries fell into desolation. The monastic cemetery took a part of the territory of the former monastery. There were buried, as I. Mitsko points out, a lot of people which came from a certain kind of Galician prince Lev Danylovych. (Myts'ko, I., 1998). Today on Chernecha mountain in Univ there is a monastic cemetery. This cemetery consists of two parts, or maybe two cemeteries are one next to another. One part is a new one, operating with fresh burials and monuments in the form of even ridges of white-stone crosses. With inscriptions. Without any sculptural or other decor. Dates, names, buried spiritual persons. This cemetery is fenced with a metal forged fence. The second part is not fenced, it has fuzzy boundaries and borders. It consists of tombstones and small irregularly scattered low white stone crosses, which are half loaded into the ground. The condition of this part of the cemetery is very poor. During the study, an inventory of all objects of the old part of the cemetery was carried out. Previously, approximately the objects date back to the 17 th century. Inventory means that the objects have been photographed, measured and described in detail. But this is every single object. The object is very interesting. This work is not finished yet and requires continuation.



Fig. 5. Object at the time of receipt for conservation



Fig. 6. Object after performing of conservation work 




Fig. 7. Object at the time of receipt for conservation

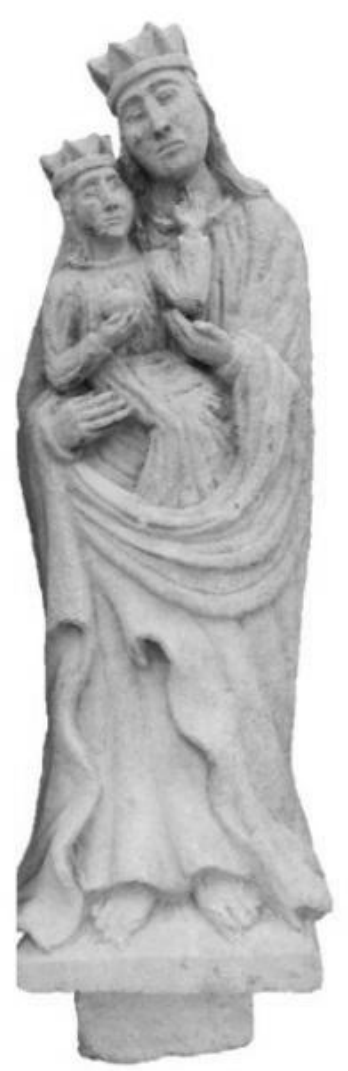

Fig. 8. Object after performing of conservation work
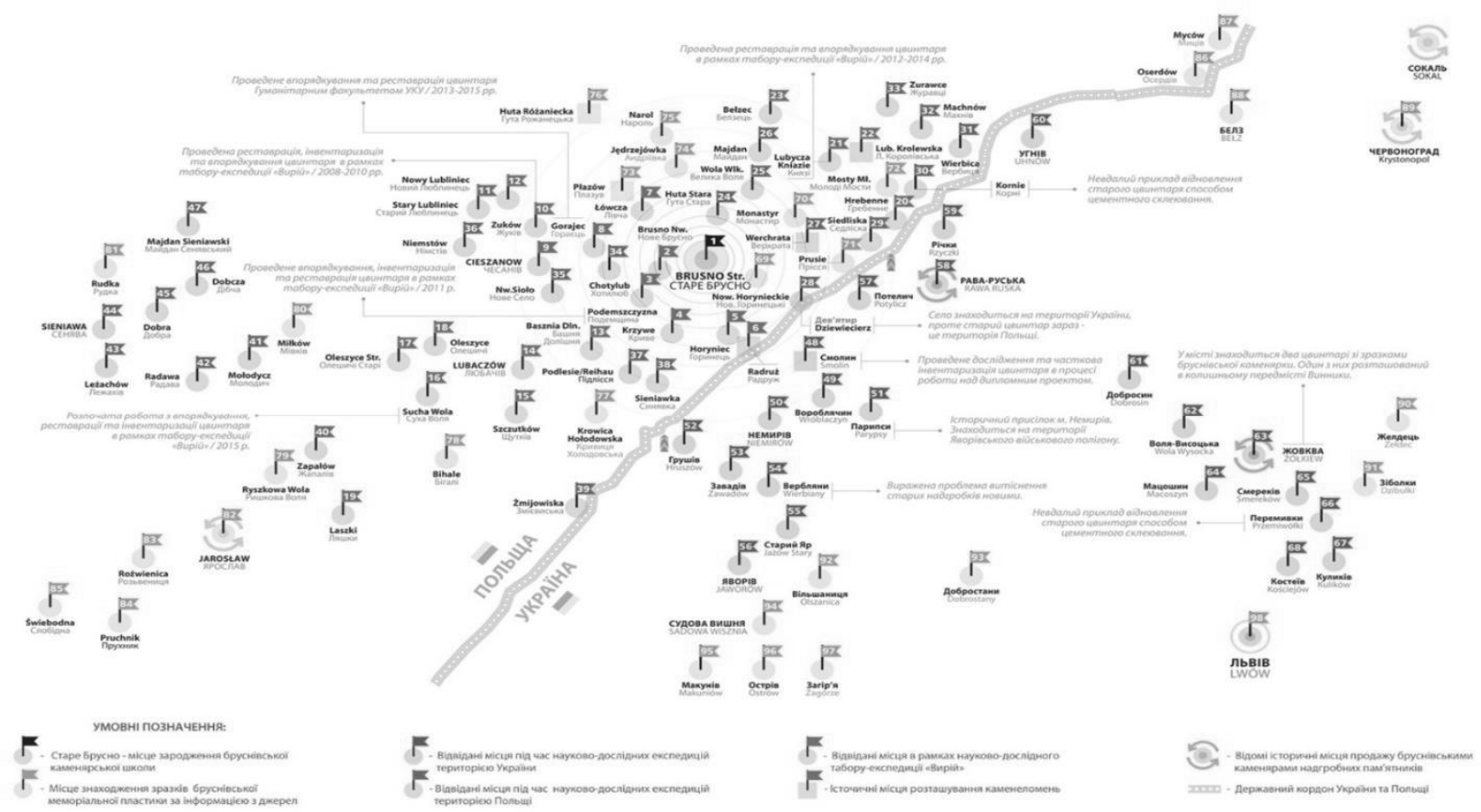

Fig. 9. A map of the distribution of the Brusno masonry school monuments 


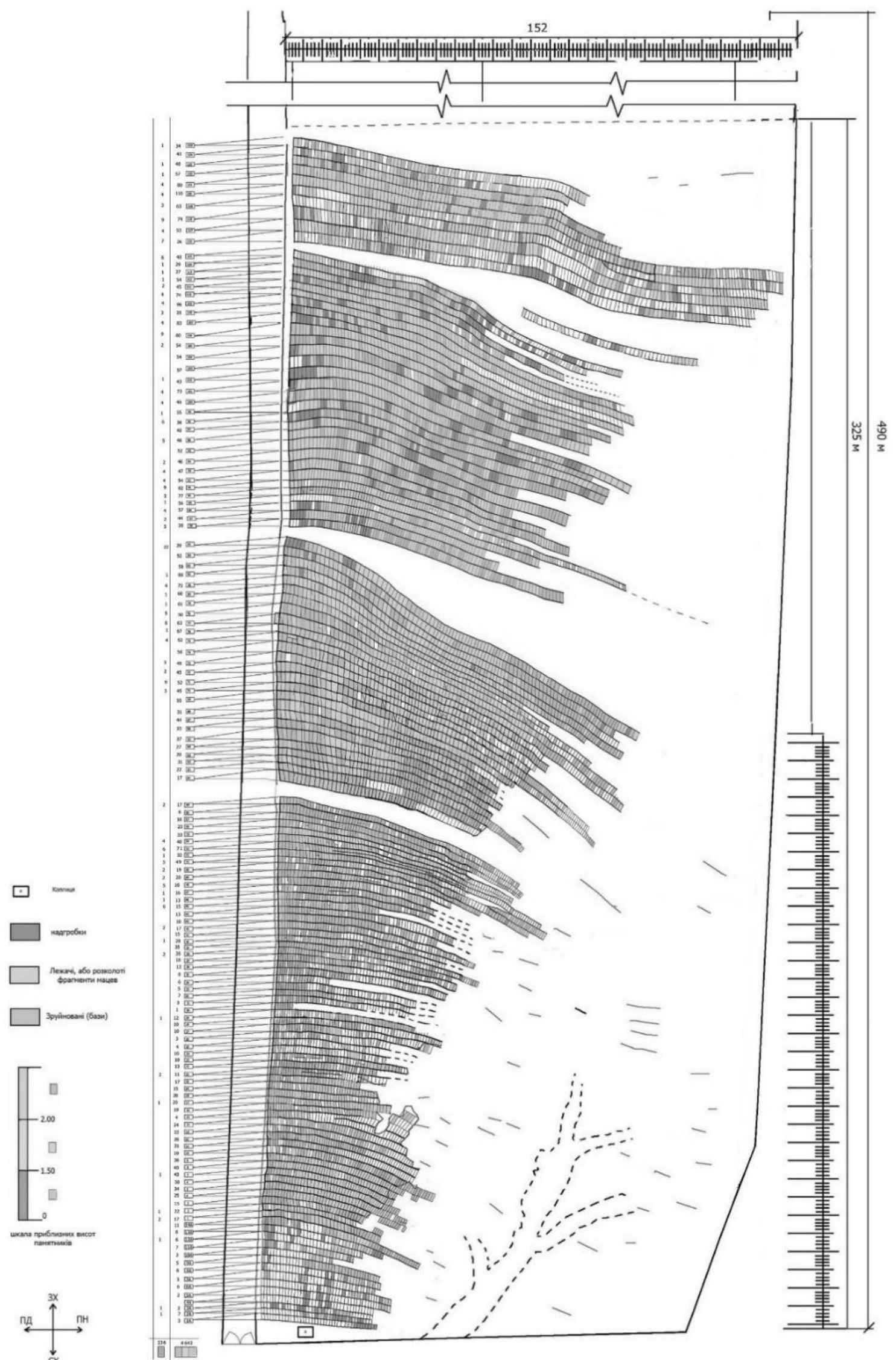

Fig. 10. Inventory the New Jewish Cemetery in Brody town 


\section{Conclusions}

In Ukraine the are more cemeteries than settlements. Many of them already today are historical cemeteries, potential monuments, and therefore require care, protection, and conservation. As mentioned, absolutely dominant material on the cemetery is a stone. Therefore, speaking about the memorial monuments conservation of the historical cemetery, we are speaking about the conservation of stone. We distinguish a number of problems that are always encountered during the conservation of the memorial monuments of the historical cemeteries. And it does not depend on the size, status or belonging of the cemetery. The first problem that you always encounter and which one needs to solve is a biodeterioration - a variety of mosses, lichens, and the like. Biology strikes every stone. This problem is hidden in the nature of the stone. And it is very dependent on the climatic conditions and circumstances in which this stone is located. Here it should be emphasized that, as it were, in a picturesque and romantic way, moss does not look on the memorial sculpture or on the cross - it must be eliminated, destroyed. The presence of any vegetation on the stone leads to the irreversible destruction of the stone. Eliminating biology from stone can only be a chemical way. And it is made by a professional restorer.

The next problem is mechanical damage. If we exclude vandalism, we must understand that the land is a rather unstable basis - it is changing, moving. It's worth remembering that many of our cemeteries are densely planted with trees. From trees fall not only leaves, but also branches, and sometimes the whole trees fall. All these factors cause mechanical damage to the monuments. Certainly any mechanical damage can be eliminated and directed, but it is a damage which provokes other damages.

The next unpleasant circumstance is the adverse climatic conditions. We can not cancel or change it, but we can take it into account and minimize it. For example, the simplest cleaning of fallen leaves in autumn is of great importance. fallen leaves that lies on the stone wet and rot causes rapid reproduction of different varieties of biology. The same fungi or later mosses. Even on a freshly cleaned or conservated stones. A similar problem is with snow. The trouble is the multiple process of freezing and melting of water. Therefore, it is better to roll off the snow that falls out immediately. That is, the problem of climate is in parallel with the problem of the lack of proper care of the objects.

The next problem is unprofessional work with a stone, as painting with incorrect paint, additions or gluing with unusual materials. Fortunately, such problems are not encountered very often, but they are very difficult to eliminate. Here, may be the educational activities can be helpful.

With regard to maximizing the preservation of existing historical cemeteries of Ukraine, it is worth considering the possibility of giving these objects a status of a monument. I hope that this status will allow to spend more time, money, efforts for taking care and ordering memorial cemeteries. And it remains to say about educational activities. If people are aware of the importance, necessity, value of such a monument as part of their history and memory then the problem of preservation will be solved.

\section{References}

[1] Bevz M., Stasyuk O. 2016. Restavraciya tvoriv my`stecztva z kamenyu. Vy`brani dy`plomni roboty`studentiv special`nosti "Restavraciya tvoriv my`stecztva z kamenyu». Magistry`, specialisty`, bakalavry`. Vy`puskny`ky`2015 r. L`viv, "Rastr-7"

[2] Bevz M., Stasyuk O. 2017. Restavraciya tvoriv my`stecztva z kamenyu. Vy`brani dy`plomni roboty` studentiv special`nosti “Restavraciya tvoriv my`stecztva z kamenyu». Magistry`, specialisty`, bakalavry`. Vy`puskny`ky`2016 r. L`viv, vy`davny`cztvo L`vivs`koyi politexniky`.

[3] Derzhavni budivel’ni normy` Ukrayiny`. Rekonstrukciya, remont, restavraciya ob'yektiv nevy`robny`choyi sfery`: restavracijni, konservacijni ta remontni roboty`na pam'yatkax kul turnoyi spadshhy`ny`, DBN V.3.2-1-2004.

[4] Kuzenko, P. 2008. Ukrayins`ke xrestorobne remeslo: istoriya ta xudozhni osobly`vosti., Visny`k DAKKKiM , Ky`yiv. S. 69-73

[5] My`cz`ko I. 1998. Svyatouspens`ka Lavra v Unevi (kinecz` XIII - kinecz`XX st.). L`viv: Svichado 
[6] Mozdy`r M. 2009. Ukrayins`ka narodna memorial`na plasty`ka. L`viv: NAN Ukrayiny` Insty`tut narodoznavstva. 286 Domasłowski W. 2011. Zabytki kamienne I metalowe, ich niszczenie I konserwacja profilaktyczna. Toruń, wydawnictwo naukowe uniwersytetu Mikolaja Kopernika

[7] Lew S. 1967- Ludowy ośrodek kamieniarski w Bruśnie, Rocznik Przemyski t. XI,

[8] Bevz M., Stasyuk O. 2016. Stone art works conservation. Selected graduated works of students of the specialty "Conservation of works of art made of stone". Masters, specialists, bachelors. Graduates in 2015 Lviv, "Raster-7".

[9] Bevz M., Stasyuk O. 2017. Stone art works conservation. Selected graduated works of students of the specialty "Conservation of works of art made of stone". Masters, specialists, bachelors. Graduates in 2016 L'viv, vydavnytstvo L'vivs'koyi politekhniky.

[10] State building norms of Ukraine. Reconstruction, repair, restoration of objects of non-productive sphere: restoration, conservation and repair works on cultural heritage monuments (SBC B.3.2-1-2004).

[11] Kuzenko, P. 2008. Ukrainian handicrafts: history and artistic peculiarities., DAKKKIM Bulletin, Kyiv. P. 69-73.

[12] Mytsko I. 1998. The Assumption Lavra in Univ (end of the 13 - the end of the 20th century). Lviv: Svichado.

[13] Mozdyr M. 2009. Ukrainian folk memorial plastic. Lviv: NAN Ukrayiny Instytut narodoznavstva. 286.

[14] Domasłowski W. 2011. Stone and metal monuments, their destruction and preventive maintenance. Toruń, a scientific publishing house of the university of Nicolaus Copernicus.

[15] Lew S. 1967. A folk stone center in Bruśnie, Rocznik Przemyski t. XI.

Олена Стасюк

\section{РЕСТАВРАЦІЯ МЕМОРІАЛЬНОЇ ПЛАСТИКИ НА ІСТОРИЧНОМУ ЦВИНТАРІ - ВИКЛИКИ ТА ПЕРСПЕКТИВИ}

Анотація. Історичні цвинтарі є невід'ємною складовою частиною культурного пейзажу кожного міста чи містечка, свідченнями ідеології $і$ духовного життя свого часу. У багатьох населених пунктах Украӥни збереглися ивинтарі, які ми тепер називаємо історичними, і які вже сьогодні є потенційними пам'ятками та становлять інтерес для дослідників та шанувальників історії, архітектури, мистецтва. Три українських ивинтарі мають статус заповідників: Державний історико-меморіальний Лук'янівський заповідник, Державний історико-культурний музей-заповідник “Личаківський ивинтар” та історично-культурний заповідник “Кладовище на Зеленій вулиці ” у Чернівиях. Цей статус має захищати їх від знищення та дає можливість проводити науково-дослідну роботу. Отже, ивинтарі у великих містах є пам'ятками-музеями або можуть ними стати. Цвинтарі невеликих населених пунктів - містечок, селищ, сіл - є меншими, зате, як правило, вони є зразками, а властиво колекціями народної меморіальної пластики.

Незалежно від розміру $і$ статусу цвинтаря в абсолютно ідеальному стані об'єкта в Украӥні нема. Кожен цвинтар вимагає безупинного догляду і впорядкування. На жаль, існує багато історичних ивинтарів, які перебувають у дуже занедбаному і жалюгідному стані. Такі цвинтарі вимагають впорядкування і реставрації, як об'єкт загалом, а також реставрації окремих зразків меморіальної пластики.

Основним матеріалом на ивинтарі є все-таки камінь, трапляється також метал, дерево та інші матеріали, але камінь однозначно домінує. Нижче йдеться про реставрачійну проблематику та методику роботи на історичному ивинтарі з меморіальними пам'ятками на прикладі дипломних робіт студентів кафедри архітектури та реставраціі Нац. ун-ти “Львівська політехніка».

Коли йдеться про реставрацію меморіальної пластики історичного иввитаря, то історія склалася таким чином, щзо багато ичих иявнтарів було частково або повністю зруйновано, знищено. Меморіальна пластика таких ивинтарів часто стає частиною музейних колекцій, лапідаріїв, деколи приватних збірок, тощьо. Такі об'єкти зазвичай потребують реставрачіï.

У статті на конкретних прикладах показано основні проблеми, які трапляються при реставрації меморіальної пластики на історичному ивинтарі. Висвітлено методи та способи, які були використані для усунення цих проблем. Зокрема музей сакрального мистецтва ім. Антона Петрушевича Львівської єпархї̈ УГКЦ. володіє великою колекцією кам'яної сакральної пластики і у 2016 і 2017 роках передає на кафедру архітектури та реставрації ряд пам'яток для проведення реставраційних робіт. Це переважно були хрести з розп'яттям з $i$ без предстоячих та фігури. Кожна з пам'яток була пошкоджена в інший спосіб і вимагала іншого підходу до реставраційних робіт. 
В рамках дипломних магістерських робіт тема реставрації меморіальної пластики історичного иввитаря розглядалася ширше ніж реставрація окремо взятого надмогильного пам'ятника. Декілька разів об'єктом реставрації виступав цілий цввинтар. А в рамках наукової роботи було досліджено ареал поширення пам'яток Бруснівської каменярської школи та накреслено алгоритм дослідження, і реставрації меморіальшої спадщини иієї школи. Подібну роботу в рамках магістерської дипломної роботи було проведено на Новому єврейському кладовищі у місті Броди. Проведено докладну і повну інвентаризацію всього ияинтаря. Було досліджено характер і особливості меморіальної різьби, а також поліхромію та кольорову символіку мачев. Крім дослідницької роботи, кожен зі студентів відреставрував по дві мацеви. I останньою з подібних робіт $\epsilon$ дослідження извинтаря на Чернечій горі в селі Уневі, щзо поблизу міста Перемишляни. Під час дослідження було проведено інвентаризацію всіх об'єктів старої частини извинтаря. Було відреставровано 2 надгробні плити. Ця робота ще не закінчена і вимагає продовження.

Виокремимо низку проблем, з якими завжди стикаємося при реставрації меморіальної пластики незалежно від розміру, статусу, приналежності ивинтаря. Перша проблема - ие біоураження. Ще однією проблемою є механічні пошкодження. Серед неприємних обставин є і несприятливі кліматичні умови. Ми не можемо їх скасувати чи змінити, але ми можемо їх врахувати і мінімізувати. Проблемою тут можемо назвати брак належного догляду за об’єктами. Наступною проблемою є непрофесійна робота з каменем, як то малювання не властивою фарбою, доповнення чи склеювання невластивими матеріалами. I залишається щзе сказати про просвітницьку діяльність. Якщзо люди усвідомлюватимуть важливість, потрібність, иінність такого пам'яткового об'єкту як історичний иявитар, як частину своєї історії $і$ пам'яті, то проблема збереження буде вирімена.

Ключові слова: консервація, меморіальні пам'ятки, природний камінь, історичне кладовище, житлові будинки, панельні будинки, “хрущовки”, реконструкиія житла, стан інженерних мереж, гаражі, життя будинків. 